The heart condition which became evident even before his return to Cheshire progressed to leave him in heart fallure which would have crippled lesser men. David remained active to the very last. This was how he wished it to be: serving the profession and community for as long as possible.

DAVID JouEY

Alan Smith

\title{
Miscellany
}

\section{Dr Mark Aveline}

Dr Mark Aveline has been elected President of the British Association for Counselling.

\section{Know How Fund - Health Sector - Small Partnershipe Scheme (Russia)}

The Health Sector Small Partnerships Scheme for Russia has been established to support non-governmental UK links with the health sector in Russia. Currently, the Know How Fund is targeting focused support to the health sector in three Oblasts: Kemerovo, Samara and Sverdlovsk. The Health Sector Small Partnerships Scheme will cover the whole of Russia and is intended to provide opportunities for initiatives in the broadly defined health field which have as a primary objective the development of partnerships between UK non-governmental organisations and non-profit centres and Russian Health Sector partners, which will lead to continuing cooperation. The fund will total $\$ 250,000$ per annum for the next two years (to mid-year 1996).

The Scheme is managed by the Charities Aid Foundation. Applications for the Scheme will be submitted to a Board which will have responsibility for project approval. For further information please contact Ms Christine Forrester, Co-ordinator, Charities Aid Foundation, 114/118 Southampton Row, London WC1B 5AA (telephone: 071831 7798; fax 0718310134 ).

\section{A national mental health charity for people of Asian origin}

Manaseek, a registered national mental health charity. has been set up to provide mental health advice, particularly to people of Asian origin living in the United Kingdom. The Manaseek Help Line telephone number is 01514263121 and advice can be provided in all the major Indian languages.

\section{Appeals for publications}

Psychiatrists in Romania would be grateful to recetve donations of back issues of The British Journal of Psychiatry. Would any Members of the College who are able to help, please contact Dr Carol Friedman, Tomis Nord, AL. HERACLEEA, No. 1, Block VI, App. 8, 8700 Constanta, Romania.

The Palestinian Institute of Mental Health would be grateful for any donations of publications related to mental health. These should be sent to: Dr Hekdyat, MAD (uk), 33A Blington Park Street, London N1 18B (telephone 071726 4114; fax 0717260880 ).

\section{New publications}

A report Alcohol Policy and the Public Good has been published by Oxford Untversity Press in association with the World Health Organization (paperback £14.99).

The Mental Health Foundation has published an information sheet on older people and mental health. Single copies are available free from Charlotte Lloyd, Information Officer, Mental Health Foundation, 37 Mortimer Street, London W1N 8JU (telephone 071580 0145).

The Manic Depression Fellowship has published a leaflet for young people with a parent with manic depression. Further information: The Manic Depression Fellowship, 8-10 High Street, Kingston upon Thames, Surrey KT1 1EY (telephone 081974 6550; fax 081974 6600). 


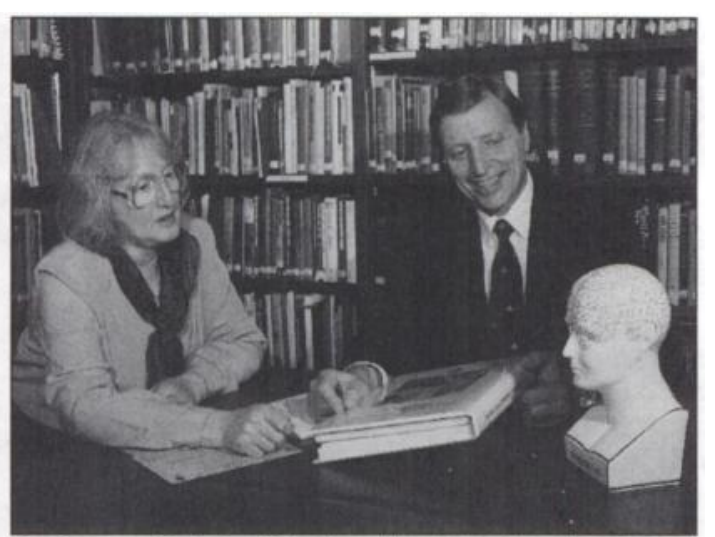

Professor Robin Priest with Mrs Liz Armstrong. Mental Health Training Officer, Division of General Practice and Primary Care, St George's Hospltal Medical School, a Member of the Defeat Depression Campaign Managerial Division.

Understanding Post-Traumatic Stress Disorder is avallable from MIND Publications, 15-19 Broadway, London E15 4BQ (telephone 081519 2122), price 45p, plus an A5 stamped addressed envelope.

\section{The Communication Award}

Professor Robin Priest led a team from the Royal College of Psychiatrists with the Royal College of General Practitioners which was shortlisted for a new national award from the Conference of Medical Royal Colleges (CMRC) in association with BUPA and the Patients Association. The Communication Award is aimed at improving the dialogue between patients and health professionals. 'Defeating Depression', the campaign entered for the award, aims to show that depression is common, recognisable and treatable. The outright winner of the Communication Award was the Freeman Hospital Newcastle for its project which encouraged patients and hospital staff to control pain levels better after operations.

\section{DEFEAT DEPRESSION CAMPAIGN FUN RUN}

\section{Sunday 9 April 1995}

11 am, Battersea Park, London Entry Fee £3.00 Distance 2 miles

Each entry fee will be matched by SmithKline Beecham and all proceeds will be put towards the funding of a Defeat Depression Campaign educational package

For an entry form and sponsor form please contact Christine Gear on 0712352351

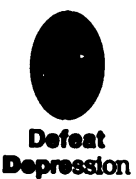

